\title{
臨床例及統計疽料
}

\section{5 例の食血思者の臨床的観祭}

\author{
屿口県 笴一病院 \\ 有焉和雄
}

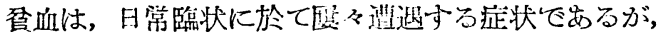

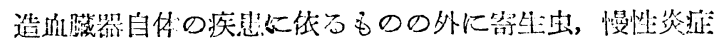

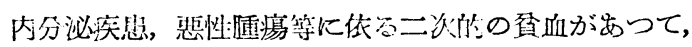
其の分類も㐨々示虬ているが，次に決々原因を買にし

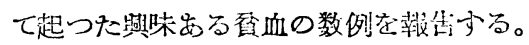

\section{第 1 例 鈎虫痘}

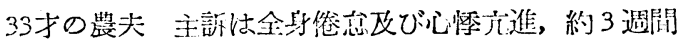

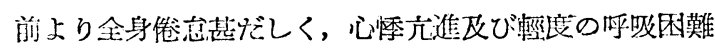
が岕つた。

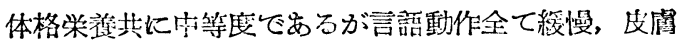

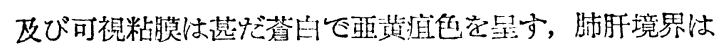

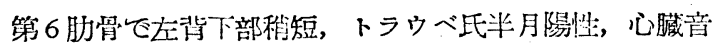
界は正常大，心音に収縮期雑音を聴く，呼吸音は微弱，

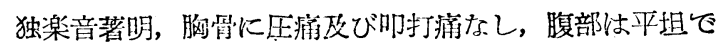
柔軟，朋を1横指触狈るが压痛なし，留区び脾は触れない， 尿は黄色透明で蛋白险性, ウロビリノーゲン陽性, 便に 多数の鈎虫卵を認奶潜血区応陽性, 血清茄田氏反応陽性,

其の後入院の!，四墟化エチンン及び四嫶化炭素に依

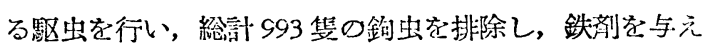
て約 1 ケ月半で栊復した。その間の血液像は第 1 蒜に示

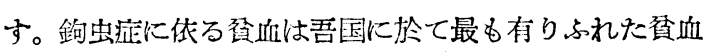
であるが，本例はその最も重㯺なるものと想われるるの

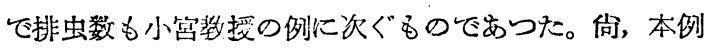
厄単球増多之好酸球減少を示した点は注目される。

\section{第 2 例，本態性栓球减少性紫斑病}

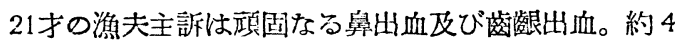

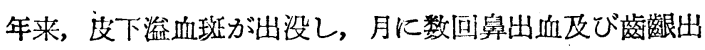
血があつた。約半年前大量の鼠出血て失神状態となり， 壊血病を疑われた事が㐫る。

全身皮嘚に点状湓血斑が散在し，可視粘償は稍蒼白，

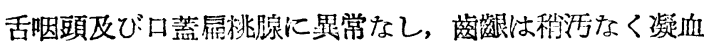

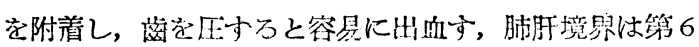
肋骨，心尖て輕度の収縮期雑音を聞く，第 2 肺動脉音秒

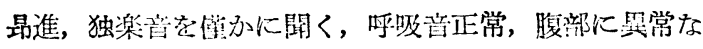

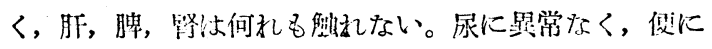

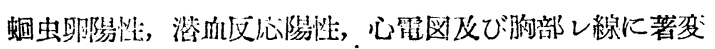

なし，血王は118-56 $\mathrm{mmHg}$ ，血清梅毒反応は全て陰性.

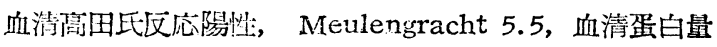
$7.48 \%$, Indophenol 设内反応 (n/Beck u Krieger) は37分て螁色乙略正常， Rumpel-Leede 現象強陽性， 出血時間 (m/Duke) は63分で著明に延長しているが 凝固時間(n/Fonio) は 7 分で略正常であつた。血飭凝縮 Jは非常に弱く Mc Farland 氏法にて測定不能, 血沈值

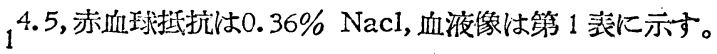
第3 例. カラアザール (Kala Azar)

¿8才の家掃，主訢は䞄血及び腹部膨隆，昭和16上恶 万 4 年間北交徐州に在佳, 炤和 18 年右温状肋膜炎に䍜 㭧, 昭和 22 年脾腄を発見さる。昭和 23 年左季肋部に 疼痛区び圧迫感力゙起り其の後㤮感戦慄を伴い約 $40^{\circ} \mathrm{CK}$

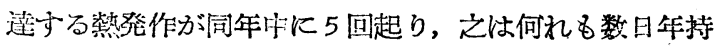
続した。渑次薈白となり，腹部か膨隆して来た。

顔に污着色があり，皮間及び可視粘膜は荟白で，リン パ睡脤はない。肺肝境界は第4 肋骨で，心濁音界は左方 に拉大し，心音は不純で第 2 肺動脉音は強く克進す。 右胸部下部に摩察音を聴取, 腹部は著明に膨隆し, 肝は 2 横指触れ，肝緑は鋭利で埊面は平滑て硬い。脾は胎下 3 鞇指に触孔，右は正中線を 3 横指越えていた，尿に罢常な く, 便は䛢便で蜔虫卵陽性, 潜血反応陰性, 胸部乙緗像は 心拉大区び右横隔膜挙上を認めた。血圧 92〜 60 mm Hg, 血清梅毒反応全て陰性，血清高田区応中等度陽性，Gros 氏反応陽性, Napier 氏反応陽性, Meulengracht 7, ᄂ 線透視で胃は砂時計胃を示し，胃液は正酸を示した。 胸骨及び 眡穿刺で形質細胞增多之共に Leishmania dovovani を証明した。ネオスチボサンに依り皮膚藷色 はなくなり，一般状態も好転し，脾も小さくなつた。血 液像第 1 表に示す。

\section{第4 例 還延性心内膜炎}

48-チの女，主訴は左季肋部の疼痛及び発熱：5年前閏 節ロイマテスに罪患す。約 1 ケ月前より $38^{\circ} \mathrm{C}$ に達する 発熱が品り，同時に左季肋部の疼痛が起つた。

皮周反び可視粘膜は鹤白で黄庭はない, 白い舌苔を認

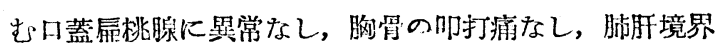


は第6 肋間腔てトラウで氏半月なし，心瀷音界は㹡大し 心尖飞収縮期雑音著明第 2 音消失, 第 2 肺動脉音は充進 す, 独楽音を聴取す, 呼吸音は正常, 腹部は平坦で肝, 脾共に 1 横指触れ何れも表面は平滑で圧痛なし, 腎は左 右共に触れ左腎は压痛著明, 尿は蛋白強陽性, 糖陰陰性 ビリルビン陰性, ウロビリノーゲン陰性，沈渣に赤血 球，白血球，腎上皮学認む，便の潜血反応陰性， 2 白血 液培養を試みたが成力せず。

入院後，3週間にして意識溷濁が起り同時に民下出血

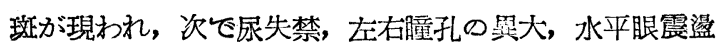

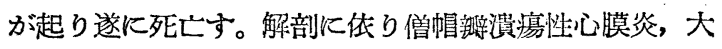

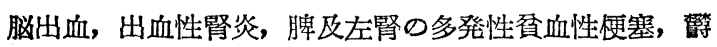
血肝を証した。省，僧帽瓣以外の辫膜に就いては著変は なかつた。血液像第 1 表に示す。筫血は発熱, 脾腔, 心 雑音等と共に本症に於ける主要症状の一であるが，特に 本例に於てはそれが甚だしかつた。

\section{第 5 例 単球性赤白血病}

48才の農夫, 主訴は荼很出血及び全身は下出血斑, 約 5 ケ月に渉る出血性傾向を訴えて吾々の所を訪れた。

皮呞薈白て全身に点状皮下溢血斑を認める。污褐色の

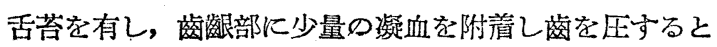
容易に出血す。胸部臓器に著変なし。胸骨に区痛あり, 腹部は平坦で肝を 2 横指触れ，脾区び腎は触れない。腋

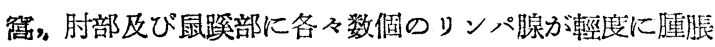
す。尿に異常なし。便に蜔虫畉中等陽性，潜血区応陰性 Rumpell-Leede 氏現象吋等陽性, 血清梅䏝区応全乙强 陽性, 血清高田氏反応陰性, Gros 氏反応陽性, 鼠永反 応陽性, Meulengracht 6.5, 出血時間 ( $n /$ Duke) 10.5 分, 凝固時間 (n/Fonio) 5.5 12分。

本例は後に脾腫が現われ，脳出血の下に死亡す。血液 像は第 2 表に示す通りで, 多教の赤茅球及び病的細胞が あつたが，此の一群の細胞は大形細胞が多く，胞依は好 塩基性でアジール顆粒があり，核は师乃至類川形で構 造は微細網状を示乙, 約 $3 / 5$ に核樎凹を認めた。核小体 は大半に 2 3 個存在し, 少数 (8\%) に Auer 氏小体 があつた。ペルオキシダーゼ区応は陽性て超生体染色て 中性紅顆粒が花冠状に集合するのを認め, 順次正常単球
への移行型が認められたので, 此等細胞は単球系所属の ものと考元た。又赤䒚球, 塩基状斑点, Howell-Golly 氏 小体 Cabot 氏環状体，多染状赤血球等多数の病的赤血 球が出現し，経過と共に正常単球が增加して㭃若単球が 少なくなり，一方赤芽球は有核血球の $17.0 \%$ を占める

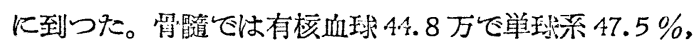
その肛正常紧球は $3.0 \%$ ，他はその幼若型で安つた赤 芽球は $29.1 \%$ ， その中 $1.3 \%$ に赤荡球を疑的せる 細胞が品つた。剖検に依り赤色膸の外に脾腫，リンパ腺 が安り, 脾, 肝, 腎, リンパ腺等に病的細胞の発潤が認 められたが，以上の所見から床例は単球性白血病と D:i Guglielmoの赤血病の合湖した単球性赤白助病と称し得 ベさ症例と考えた゚

各種血球の生成立びに成熟障碍を主原因とする一連の 疾思, 即ち顆粒球減少症, 柾球減少性紫斑病, 再生不良

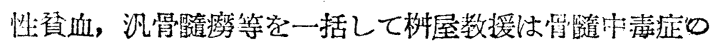
名を提唱して，同一原因て此等湩々の疾思の起り得る事 を多数症例を举げて証明している。実際吾ふが顆糔球減 少と云万時に顆粒球の外に, 赤血球系や栓球も闹時に或 方程度侵されている事が多いのと同じく丽生不艮性得血 の際に赤助球采の外に白血琲系, 栓球系の生成成熟障碍

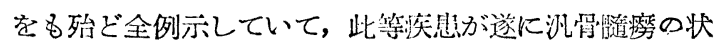

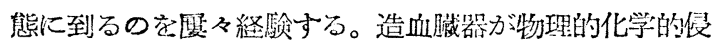
瑟を受けた際に，或る血球系が純粹に単独に侵されるの

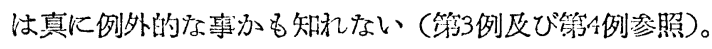
そ乙て再生不良性皿球減少症 (例兄ば再生不良性筫血,

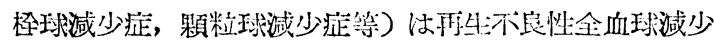

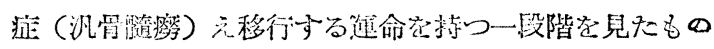

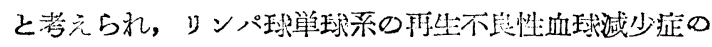
例は知らないが，此は此等血球の先理的正常僆が少ない ので其の洔期に発見出来ず优の血球系が闰時に侵された

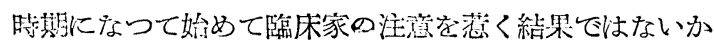
と考えれる。更に一過性の血球減少症之再生不良性血球 減少症の鑑別に就いても現在佾幾多の疑聞が残つている が, 将来霓に症例を重水る事に体り考察を進め度いと考 える。

第 1 表

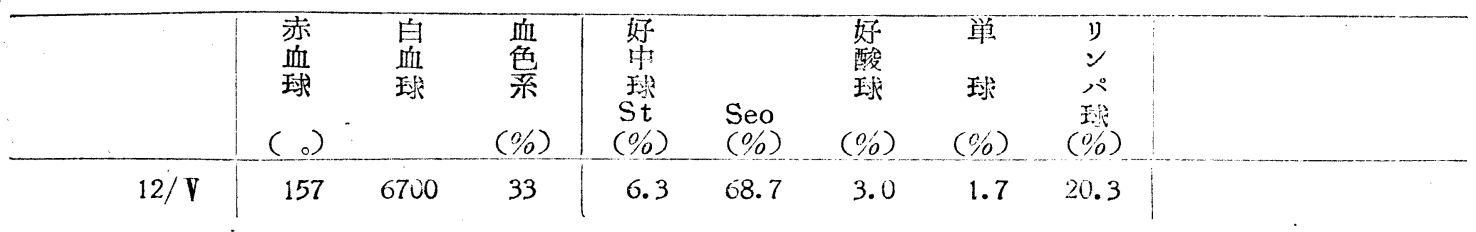




\begin{tabular}{|c|c|c|c|c|c|c|c|c|c|c|c|}
\hline \multirow[t]{2}{*}{ 第 1 例 } & $19 / \mathbf{V}$ & 124 & 9700 & 23 & 10.5 & 70.0 & 0 & 8.5 & 11.0 & & \\
\hline & $29 / v$ & 431 & 9200 & 98 & 8.5 & 71.0 & 2.5 & 5.5 & 12.5 & & \\
\hline \multirow{2}{*}{ 第 2 例 } & & 312 & 7100 & 38 & 8.0 & 54.0 & 10.0 & 7.0 & 21.0 & \multicolumn{2}{|l|}{ 梭球 0\% } \\
\hline & & 415 & 8300 & 68 & 37.5 & 31.5 & 9.0 & 2.5 & 19.5 & \multicolumn{2}{|l|}{$\begin{array}{c}\text { 柾球 白血球 } \\
495 \quad 200\end{array}$} \\
\hline \multirow{4}{*}{ 第3 例 } & $16 / 11$ & 119 & 3200 & 40 & 15.0 & 30.5 & 0 & 22.0 & 32.0 & \multirow[t]{4}{*}{ 赤茅球0.5\% } & \multirow[t]{4}{*}{ 栓球 41800} \\
\hline & $28 /$ VII & 338 & 4100 & 41 & 22.0 & 18.0 & 0 & 20.5 & 39.5 & & \\
\hline & $11 /$ III & 271 & 4500 & 一 & 26.5 & 20.5 & 0 & 18.5 & 30.5 & & \\
\hline & $12 / \mathrm{IX}$ & 266 & 4600 & 40 & 15.0 & 52.0 & 4.0 & 4.0 & 25.0 & & \\
\hline 第 4 例 & & 143 & 2,100 & 28 & 23 & 53 & 0 & 3 & 12 & & \\
\hline
\end{tabular}

第 2 表

\begin{tabular}{|c|c|c|c|c|c|c|c|c|c|c|c|c|c|}
\hline & & $\begin{array}{l}\text { 赤 } \\
\text { 血 } \\
\text { 球 }\end{array}$ & $\begin{array}{l}\text { 有 } \\
\text { 检 } \\
\text { 血 } \\
\text { 球 }\end{array}$ & & 素 & $\begin{array}{l}\text { 赤 } \\
\text { 茅 } \\
\text { 球 }\end{array}$ & $\mathrm{I}^{\text {若 }}$ & II & 単 & $\begin{array}{l}\text { 好 } \\
\text { 中 } \\
\text { 球 }\end{array}$ & $\begin{array}{l}\text { 好 } \\
\text { 酸 } \\
\text { 球 }\end{array}$ & $\begin{array}{l}\text { ソ } \\
\text { ソ } \\
\text { パ } \\
\text { 球 }\end{array}$ & \\
\hline \multirow{4}{*}{ 第5 例 } & $8 / \mathrm{X}$ & 295 & 40000 & & 51 & 27.5 & & 51.0 & & 11.0 & 4.0 & 6.5 & \multirow{4}{*}{ 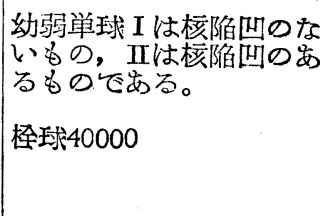 } \\
\hline & $9 /$ IX & $2 \mathrm{C4}$ & 40400 & & 51 & 28.5 & 23.0 & 31.5 & 3,5 & 6.5 & 2.0 & 5.0 & \\
\hline & $16 / \mathbb{X}$ & $2 C 0$ & $400=0$ & & 50 & 33.5 & 28.5 & 24.5 & 3.0 & 3.0 & 3.5 & 4.0 & \\
\hline & $20 / 1 X$ & 89 & 38000 & & 29 & 47.0 & 2.0 & 11.5 & 24.0 & 9.5 & 1.5 & 4.5 & \\
\hline \multirow[t]{2}{*}{$\begin{array}{l}\text { 䈍5例 } \\
\text { 骨㵦 }\end{array}$} & \multirow[t]{2}{*}{$16 /$ IX } & $\begin{array}{l}\text { 有 } \\
\text { 核 } \\
\text { 血 } \\
\text { 球 } \\
\text { (方) }\end{array}$ & $\begin{array}{l}\text { 导 } \\
\text { 㫱 } \\
\text { 芽 } \\
\text { 球 }\end{array}$ & $\begin{array}{l}\text { 大 } \\
\text { 赤 } \\
\text { 芽 } \\
\text { 球 }\end{array}$ & $\begin{array}{l}\text { 正 } \\
\text { 䞑 } \\
\text { 芽到 }\end{array}$ & 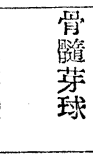 & $\begin{array}{l}\text { 好 } \\
\text { 中 } \\
\text { 球 }\end{array}$ & $\begin{array}{l}\text { 好 } \\
\text { 酸 } \\
\text { 球 }\end{array}$ & $\begin{array}{l}\text { 㓜 } \\
\text { 若 } \\
\text { 緟 } \\
\text { 球 }\end{array}$ & 単 & $\begin{array}{l}\text { リ } \\
\text { ソ } \\
\text { 球 }\end{array}$ & $\begin{array}{l}\text { 形 } \\
\text { 頎 } \\
\text { 細 } \\
\text { 胞 }\end{array}$ & \\
\hline & & 44.8 & 1.3 & 4.3 & 23.5 & 5.7 & 11.4 & 1.3 & 44.5 & 3.0 & 3.8 & 1.2 & \\
\hline
\end{tabular}

\section{（鈎虫症）}

\section{参考文献}

1）宮川，日本医亨新報No.1310昭24.6，2）楠井，中 島, 診断之治療4, 37. 昭24.4，3） 久留宮, 西田, 小泉, 綜合医学5,11, 昭23.6，4）小剩，実験医報268，昭12. 2，5）宮本，臨内小，2号4卷 昭24.2，6）小宮，医学 4号2卷昭 $22.4 ， 7$ ) 北山, 浜野, 診療の実際7号 1 卷 昭 $25.7,8 ）$ 宮崎, 日血誌 12 卷 4 号昭 24 .

(栓球減少症)

佐野，西屋：日本内科臨床選集，第3集 昭24 保利，管 田, 日血誌12卷4号 昭 24 三浦, 松田, 日血誌 13 卷4号 昭25

(カラアザール)

操, 前田 : 臨床と研究23卷12号昭21 服部, 方吉, 血液 学討議会報告第2輯 19.49 福北, 永井, 日血誌 9 然 3 号 昭21富田, 実地医家卜臨床20卷 9 号昭 18 上条: 綜合 医学5卷11号 北村, 䜿内小, 3卷5号昭23.5 Whitby and Britton. : Disoder of the Blood. 1535. Carl Mense.: Handbnch der Tropenkrankheiten 1926. Joseph McFarland, Pathogenic Bacteria and Protozoa 1916, W. Kolle u. A. V. Wassermann. Han- dbuch der Pathogenen Mikro-organismen 913. 福井, 永井野，飯島，日血誌 11 卷 3,4号昭23.

(要延性心内膜炎)

三浦，干井：日血誌13卷 4 号昭25 伊藤，原田，長谷川 日血誌 15 卷 4 号昭 27 三力：日内会誌 41 卷 9 号昭 27 .

\section{(赤白血病, 単球白血病)}

林, 内藤, 横山: 臨内小, 7 叁10号昭27.10. 勝沼, 興 不, 川久保, 日血誌 14 卷 4 号昭26.8 重谷, 早田, 日血 誌14焱 4 号昭 26.8 桝屋, 有馬, 日血誌 14 卷4号昭 26.8 草間, 田辺, 日血誌14卷4昂昭26.8. 林, 竹之内, 日血 誌14卷4厉昭26.8 小宮, 河北, 白血病馀交集昭26.9,

Reschadiu.von Chilling : Münch. m. Wschr.60. 1913 Fleischmann D.: Fol. Haemat. 20. 1916. W. Schultz: Fol. Haemat.63.1940. 浜口, 永野, 白血病, 研修畫房 昭21.河北：日近九地誌， 2 発 2 号昭 26.

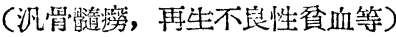

菅野，高尾：日血誌13突 1 号昭25. 掃部, 大口, 吉岡 日血誌 13 龙 2 号昭25. 稻田, 平井, 日血誌, 14 卷 2 号 昭26. 柝屋, 日血九地誌 2 妴 1 号昭26. 栘腛, 原, 門 田, 日血誌 14 卷 4 号炤26. 井上:日血儿誌 2 卷 3 号昭 26. 井上: 臨休と研究. 26 然 4 号. 昭 24 . 